\title{
FCRL5 Gene
}

National Cancer Institute

\section{Source}

National Cancer Institute. FCRL5 Gene. NCI Thesaurus. Code C123872.

This gene may play a role in the development, differentiation and immunoregulation of B-cells. 